\title{
PENINGKATAN KOMPETENSI PEDAGOGIK MERANCANG PROGRAM PENGAYAAN GURU SDN 4 JIKEN MELALUI SUPERVISI AKADEMIK TEKNIK PENILAIAN DIRI SENDIRI SEMESTER II TAHUN PELAJARAN 2018/2019
}

\author{
Pujiati \\ Kepala SDN 4 Jiken, Kec. Jiken, Kab. Blora \\ Email: pujiati_jiken@yahoo.com
}

\begin{abstract}
The purpose of this research is to analyze the increasing of the teachers' pedagogical competencies in designing the enrichment program through academic supervision with self assessment on the second semester of the 2018/2019 year academic. This research is a School Action Research (SAR). The location of this research is Elementary School of 4 Jiken, Sub district of Jiken, Regency of Blora. The time of this research is early the first Semester of the 2018/2019 year academic. The subjects of this research are six class teachers (CT) and three subject teachers (ST). Technique of collecting data of this research is non test technique. The instruments of collecting data of this research are the sheets of self assessment, the sheets of observation and documentation. Technique of analyzing data of this research is comparative description. The procedure of this research is using Cycle Model. This research is going on two cycles. The results of this research are 1) pedagogical competencies in designing the enrichment program are increasing lack of competent category (D) become competent category (B) dan pedagogical competencies in designing the enrichment program including in competent category are increasing from $0 \%$ on the Early Condition become 22,23\% on the First Cycle and 88,88\% on the Second Cycle.

Keywords: Pedagogical Competencies, The Enrichment Program, Academic Supervision, Self Assessment

Abstrak

Tujuan penelitian ini adalah menganalisis peningkatan kompetensi pedagogik merancang program pengayaan Guru SDN 4 Jiken melalui supervisi akademik teknik penilaian diri sendiri Semester II Tahun Pelajaran 2018/2019. Penelitian ini termasuk dalam jenis Penelitian Tindakan Sekolah (PTS). Tempat penelitian di SDN 4 Jiken, Kecamatan Jiken, Kabupaten Blora. Waktu penelitian pada awal Semester II Tahun Pelajaran 2018/2019. Subjek penelitian adalah enam Guru Kelas (GK) dan tiga Guru Pelajaran (GP). Teknik pengumpulan data penelitian ini dengan teknik nontes. Alat pengumpulan data penelitian ini dengan lembar penilaian diri sendiri, lembar pengamatan dan dokumentasi. Teknik analisis data penelitian ini adalah deskriptif komparatif. Prosedur penelitian ini menggunakan Model Siklus. Penelitian selama dua siklus. Hasil penelitian ini adalah 1) kompetensi pedagogik merancang program pengayaan meningkat dari kategori kurang berkompeten (D) menjadi kategori berkompeten (B) dan 2) kompetensi pedagogik merancang program pengayaan yang termasuk kategori berkompeten (B) meningkat dari 0\% pada Kondisi Awal menjadi 22,23\% pada Siklus I dan $88,88 \%$ pada Siklus II.
\end{abstract}

Kata Kunci: Kompetensi Pedagogik, Program Pengayaan, Supervisi Akademik, Penilaian Diri Sendiri.

\section{PENDAHULUAN}

Sekolah merupakan lembaga yang bersifat kompleks dan unik. Kompleks karena sekolah merupakan organisasi yang di dalamnya terdapat berbagai dimensi yang satu sama lain saling berkaitan dan saling menentukan. Unik karena sekolah mempunyai ciri-ciri tertentu yang tidak dimiliki organisasi-organisasi lain. Karena sifatnya yang kompleks dan unik itulah sekolah menjadi organisasi yang memerlukan koordinasi yang tinggi. Keberhasilan sekolah menjadi keberhasilan kepala sekolah.

Sekolah merupakan lembaga pendidikan formal dengan pembelajaran sebagai kegiatan utama. Dengan demikian, guru menjadi faktor utama yang sangat penting dalam pengelolaan pembelajaran tersebut. Pembelajaran tidak hanya sekedar diawali dengan perencanaan, dilaksanakan sesuai dengan prosedur dan diakhiri dengan evaluasi. Dalam evaluasi tersebut, guru menindaklanjuti dengan program remedial bagi peserta didik yang belum tuntas dan program pengayaan bagi peserta didik yang sudah tuntas.

Dalam Pasal 135 Peraturan Pemerintah Nomor 17 Tahun 2010 tentang Pengelolaan Penyelenggaraan Pendidikan, pendidikan khusus bagi peserta didik yang memiliki kecerdasan dan/atau bakat istimewa dapat diselenggarakan pada satuan pendidikan formal dan dapat berupa program percepatan dan/atau program pengayaan. Program percepatan dilakukan oleh satuan pendidikan yang telah atau hampir memenuhi Standar Nasional Pendidikan (SNP) dalam bentuk kelas biasa, kelas khusus atau satuan pendidikan khusus. 
Sedangkan program pengayaan adalah program pembelajaran yang dirancang untuk memberikan kesempatan kepada peserta didik guna mencapai kompetensi lebih luas dan/atau lebih dalam dari Standar Isi (SI) dan Standar Kompetensi Lulusan (SKL).

Menurut Sukiman (2012: 52), program pengayaan adalah kegiatan yang diberikan kepada peserta didik kelompok cepat, sehingga peserta didik tersebut lebih kaya pengetahuan dan keterampilannya lebih mendalam terhadap penguasaan bahan pelajaran dan kompetensi yang mereka pelajari. Menurut Sugihartono (2012: 186), program pengayaan adalah kegiatan yang ditujukan bagi peserta didik yang memiliki kemampuan akademik yang tinggi, yang berarti mereka adalah peserta didik yang tergolong cepat dalam menyelesaikan tugas belajarnya. Menurut Kunandar (2013: 240-241), program pengayaan adalah program pembelajaran yang diberikan kepada peserta didik yang belajar lebih cepat.

Pengayaan merupakan pembelajaran tambahan dengan tujuan untuk memberikan kesempatan pembelajaran baru bagi peserta didik yang mempunyai kelebihan sedemikian rupa, sehingga mereka dapat mengoptimalkan perkembangan minat, bakat dan kecakapannya. Pengayaan berupaya mengembangkan keterampilan berpikir, kreativitas, pemecahan masalah, eksperimen, inovasi, inovasi, penemuan, keterampilan seni maupun gerak dsb. Pengayaan merupakan tantangan belajar yang lebih tinggi untuk membantu peserta didik mencapai kapasitas optimal dalam belajarnya. Pengayaan merupakan program yang memperhatikan prinsip perbedaan individu untuk memenuhi kebutuhan atau hak peserta didik. Oleh karena itu, guru memfasilitasi peserta didik untuk memperkaya wawasan dan keterampilannya serta mengaplikasikannya dalam kehidupan sehari-hari.

Pengayaan sebagai kesatuan program dalam pembelajaran maupun evaluasi hasil belajar dirancang pada tahap perencanaan pembelajaran secara sistematis, sehingga siap dilaksanakan sesuai dengan analisis terhadap proses dan hasil belajar. Tanpa perencanaan tersebut, pengayaan terabaikan dan sulit dilaksanakan secara proporsional. Pada kenyataannya, pengayaan lebih sering terabaikan dan sulit dilaksanakan daripada remedial.

Dari hasil kunjungan kelas dan percakapan individual dengan guru SDN 4 Jiken, Kecamatan Jiken, Kabupaten Blora, hasilnya adalah 1) guru fokus pada perencanaan dan pelaksanaan pembelajaran, 2) guru lebih mengutamakan program remedial daripada program pengayaan, 3) guru belum mempunyai kompetensi pedagogik yang layak tentang program pengayaan, sehingga tidak merancang program pengayaan, 4) guru tidak mempunyai program pengayaan yang sistematis, sehingga tidak melaksanakan program pengayaan bagi peserta didik yang belajar dengan cepat. Secara keseluruhan, kompetensi pedagogik guru dalam merancang program pengayaan dengan persentase sebesar $49,44 \%$ yang termasuk kategori kurang berkompeten (D).

Menurut Prasojo dan Sudiyono (2011: 108), penilaian diri sendiri adalah penilaian yang dilakukan oleh diri sendiri secara objektif. Dalam penilaian diri sendiri diperlukan kejujuran diri sendiri. Menurut Risnawati (2012: 259), penilaian diri sendiri secara objektif membantu guru dalam memperbaiki kemampuannya.

Supervisi akademik teknik penilaian diri sendiri merupakan tindak lanjut terhadap kompetensi pedagogiknya dalam merancang program pengayaan. Guru menilai dirinya sendiri secara objektif sesuai dengan kompetensi pedagogiknya dalam merancang program pengayaan. Sesuai dengan penilaian diri sendiri, guru menyatakan penguasaan materi maupun permasalahan yang masih terjadi, sehingga penulis memberikan bimbingan secara terarah yang memperkuat kompetensi pedagogiknya.

Sesuai dengan uraian dalam latar belakang di atas, penulis sebagai Kepala SDN 4 Jiken, Kecamatan Jiken, Kabupaten Blora berinisiatif melakukan supervisi akademik untuk meningkatkan kompetensi akademik guru dalam merancang program pengayaan. Supervisi akademik dilakukan dengan teknik penilaian diri sendiri sesuai cek lis yang tersedia. Dengan supervisi akademik kepala sekolah diharapkan dapat meningkatkan kompetensi pedagogik guru dalam merancang program pengayaan. 


\section{METODE PENELITIAN}

Penelitian ini termasuk dalam jenis Penelitian Tindakan Sekolah (PTS). Penulis merupakan Kepala SDN 4 Jiken, Kecamatan Jiken, Kabupaten Blora. Tindakan dalam penelitian ini adalah penilaian diri sendiri.

Tempat penelitian di SDN 4 Jiken, Kecamatan Jiken, Kabupaten Blora. Tempat penelitian beralamat di Jalan Balongan Kalitengah, Kelurahan Jiken, Kecamatan Jiken,
Kabupaten Blora. Tempat penelitian terletak di areal persawahan, sehingga cukup terpencil. Tempat penelitian cukup terjangkau dari lembaga pendidikan formal sejenis, yaitu SDN 2 Jiken yang terletak di jalur utama transportasi.

Waktu penelitian pada awal Semester II Tahun Pelajaran 2018/2019 sesuai dengan jadwal pelajaran dan jadwal kegiatan. Waktu penelitian sesuai dengan tabel sebagai berikut"

Tabel 3.1. Jadwal Kegiatan Penelitian.

\begin{tabular}{|c|c|c|c|c|c|c|c|c|c|c|c|c|}
\hline \multirow{2}{*}{ No } & \multirow{2}{*}{ Kegiatan } & \multicolumn{4}{|c|}{ Februari } & \multicolumn{4}{|c|}{ Maret } & \multicolumn{3}{|c|}{ April } \\
\hline & & 1 & 2 & 3 & 4 & 1 & 2 & 3 & 4 & 1 & 2 & 3 \\
\hline 1 & Identifikasi Masalah & 25 & 25 & & & & & & & & & \\
\hline 2 & Proposal Penelitian & & 25 & 25 & 2 & & & & & & & \\
\hline 3 & Pengumpulan Data & & & & & & & & & & & \\
\hline & a. Siklus I & & & & 8 & 25 & es & & & & & \\
\hline & b. Siklus II & & & & & & & 25 & 25 & 25 & & \\
\hline 4 & Pengolahan Data & & & & es & 25 & $\mathscr{E}$ & 25 & es & 25 & & \\
\hline 5 & Penyusunan Laporan & & & & & 2 & 2 & 2 & 2 & 25 & 25 & \\
\hline 6 & Seminar & & & & & & & & & & & $\mathscr{E}$ \\
\hline
\end{tabular}

Subjek penelitian adalah Guru Kelas (GK) dan Guru Pelajaran (GP) di SDN 4 Jiken, Kecamatan Jiken, Kabupaten Blora yang terdiri dari enam GK dan tiga GP. Subjek penelitian sesuai dengan tabel sebagai berikut:

Tabel 3.2. Subjek Penelitian.

\begin{tabular}{|c|l|l|}
\hline No & \multicolumn{1}{|c|}{ Nama } & \multicolumn{1}{c|}{ Tugas } \\
\hline 1 & Sumerundari, S.Pd.SD. & Guru Kelas I \\
\hline 2 & Sunarti, S.Pd.I & Guru PABP Kelas I-VI \\
\hline 3 & Retno Jumeiarsih, A.Ma.Pd. & Guru PJOK Kelas I dan III \\
\hline 4 & Ratih Puspitasari, S.Pd. & Guru PJOK Kelas II, IV-VI \\
\hline 5 & Eni Tri Handayani, S.Pd.SD. & Guru Kelas VI \\
\hline 6 & Reni Dwi Apriyani, S.Pd. & Guru Kelas II \\
\hline 7 & Windha Suluh Winanti, S.Pd. & Guru Kelas V \\
\hline 8 & Sulastri, S.Pd. & Guru Kelas IV \\
\hline 9 & Siti Kumaidah, S.Pd. & Guru Kelas III \\
\hline
\end{tabular}

Teknik pengumpulan data penelitian ini dengan teknik nontes. Sedangkan alat pengumpulan data penelitian ini dengan lembar penilaian diri sendiri, lembar pengamatan dan dokumentasi.

Teknik analisis data penelitian ini adalah deskriptif komparatif. Teknik analisis data penelitian ini bersifat kualitatif dan kuantitatif. Prosedur penelitian ini menggunakan Model
Siklus yang terdiri dari empat tahap, yaitu perencanaan, tindakan, pengamatan dan refleksi. Penelitian selama dua siklus.

\section{HASIL PENELITIAN DAN PEMBAHASAN Deskripsi Kondisi Awal}

Kompetensi pedagogik guru dalam merancang program pengayaan dengan persentase sebesar $49,44 \%$ yang termasuk 
kategori kurang berkompeten (D). Sesuai dengan identifikasi masalah diketahui 1) guru fokus pada perencanaan dan pelaksanaan pembelajaran, 2) guru lebih mengutamakan program remedial daripada program pengayaan, 3) guru belum mempunyai kompetensi pedagogik yang layak tentang program pengayaan, sehingga tidak merancang program pengayaan, 4) guru tidak mempunyai program pengayaan yang sistematis, sehingga tidak melaksanakan program pengayaan bagi peserta didik yang belajar dengan cepat. Secara lengkap, kompetensi pedagogik guru dalam merancang program pengayaan sesuai supervisi akademik dengan teknik penilaian diri sendiri sebagai berikut:

Tabel 4.1. Kompetensi pedagogik guru dalam merancang program pengayaan.

\begin{tabular}{|c|l|c|c|}
\hline No & \multicolumn{1}{|c|}{ Nama } & Persentase & Kategori \\
\hline 1 & SUM & 42,5 & $\mathrm{D}$ \\
\hline 2 & SUN & 52,5 & $\mathrm{D}$ \\
\hline 3 & RET & 35 & $\mathrm{D}$ \\
\hline 4 & RAT & 57,5 & $\mathrm{D}$ \\
\hline 5 & ENI & 60 & $\mathrm{C}$ \\
\hline 6 & REN & 47,5 & $\mathrm{D}$ \\
\hline 7 & WIN & 60 & $\mathrm{C}$ \\
\hline 8 & SUL & 55 & $\mathrm{D}$ \\
\hline 9 & SIT & 35 & $\mathrm{D}$ \\
\hline & Rata-rata persentase & 49,44 & $\mathrm{D}$ \\
\hline
\end{tabular}

Sesuai dengan analisis data di atas, maka kompetensi pedagogik guru dalam merancang program pengayaan tidak ada yang termasuk kategori berkompeten (B). Kompetensi pedagogik guru hanya termasuk kategori cukup berkompeten (C) sebesar 22,23\% dan kategori kurang berkompeten sebesar $77,77 \%$. Dengan demikian, kompetensi pedagogik guru dalam merancang program pengayaan hanya termasuk kategori kurang berkompeten (D).

\section{Deskripsi Siklus I}

Penulis melakukan bimbingan dan pembinaan kepada subjek penelitian tentang program pengayaan. Materi adalah kajian teori tentang program pengayaan. Kemudian, subjek penelitian merancang dan melaksanakan program pengayaan sesuai dengan hasil belajar terdahulu. Hasilnya adalah 1) kompetensi pedagogik guru merancang program pengayaan dengan persentase sebesar $61,67 \%$ yang termasuk kategori cukup berkompeten $(\mathrm{C}), 2$ ) kompetensi guru merancang program pengayaan yang termasuk kategori berkompeten (B) dengan persentase sebesar 22,23\%, 3) kompetensi pedagogik guru melaksanakan program pengayaan dengan persentase sebesar $65,74 \%$ yang termasuk kategori cukup berkompeten (C) dan 4) kompetensi guru melaksanakan program pengayaan yang termasuk kategori berkompeten (B) dengan persentase sebesar 33,33\%.

Sesuai dengan analisis pada Siklus I di atas, maka penulis memperoleh refleksi sebagai berikut:

Tabel 4.4. Refleksi pada Siklus I.

\begin{tabular}{|c|l|c|c|}
\hline No & \multicolumn{1}{|c|}{ Indikator keberhasilan tindakan } & Pencapaian & Refleksi \\
\hline 1 & $\begin{array}{l}\text { Rata-rata kompetensi guru merancang program } \\
\text { pengayaan termasuk kategori berkompeten (B) }\end{array}$ & $61,67 \%(\mathrm{C})$ & $\begin{array}{c}61,67 \% \leq \\
71 \%-85 \%\end{array}$ \\
\hline 2 & $\begin{array}{l}\text { Kompetensi guru merancang program pengayaan } \\
\text { yang termasuk kategori berkompeten (B) minimal } \\
\text { memenuhi 75\% }\end{array}$ & $22,23 \%$ & $22,23 \% \leq 75 \%$ \\
\hline 3 & $\begin{array}{l}\text { Rata-rata kompetensi guru melaksanakan program } \\
\text { pengayaan termasuk kategori berkompeten (B) }\end{array}$ & $65,74 \%$ (C) & $\begin{array}{l}65,74 \% \leq \\
71 \%-85 \%\end{array}$ \\
\hline 4 & $\begin{array}{l}\text { Kompetensi guru melaksanakan program pengayaan } \\
\text { yang termasuk kategori berkompeten (B) minimal } \\
\text { memenuhi 75\% }\end{array}$ & $33,33 \%$ & $33,33 \% \leq 75 \%$ \\
\hline \multicolumn{1}{|c|}{ Keputusan } & \multicolumn{2}{|c|}{ Tidak berhasil } \\
\hline
\end{tabular}


Sesuai dengan analisis data dan refleksi pada Siklus I, maka kompetensi pedagogik guru merancang program pengayaan meningkat dan termasuk kategori cukup berkompeten (C). Kompetensi pedagogik guru merancang program pengayaan mengalami peningkatan dari kategori kurang berkompeten (D) menjadi cukup berkompeten (C). Namun peningkatan tersebut belum memenuhi indikator keberhasilan tindakan. Dengan demikian, tindakan pada Siklus I belum mampu meningkatkan kompetensi pedagogik guru merancang program pengayaan yang termasuk kategori berkompeten (B).

Sesuai dengan analisis data dan refleksi pada Siklus I, maka pembaruan tindakan pada Siklus II adalah bimbingan dan pembinaan tentang teknis, yaitu format dan sistematika tentang program pengayaan.

\section{Deskripsi Siklus II}

Penulis melakukan bimbingan dan pembinaan kepada subjek penelitian tentang bimbingan teknis. Materi adalah format dan sistematika tentang program pengayaan. Kemudian, subjek penelitian merancang dan melaksanakan program pengayaan sesuai dengan proses dan hasil belajar berikutnya. Hasilnya adalah 1) kompetensi pedagogik guru merancang program pengayaan dengan persentase sebesar $81,38 \%$ yang termasuk kategori berkompeten (B), 2) kompetensi guru merancang program pengayaan yang termasuk kategori berkompeten (B) dengan persentase sebesar 88,88\%, 3) kompetensi pedagogik guru melaksanakan program pengayaan dengan persentase sebesar $84,25 \%$ yang termasuk kategori berkompeten (B) dan 4) kompetensi guru melaksanakan program pengayaan yang termasuk kategori berkompeten (B) dengan persentase sebesar $100 \%$.

Sesuai dengan analisis pada Siklus II di atas, maka penulis memperoleh refleksi sebagai berikut:

Tabel 4.7. Refleksi pada Siklus II.

\begin{tabular}{|c|l|c|c|}
\hline No & \multicolumn{1}{|c|}{ Indikator keberhasilan tindakan } & Pencapaian & Refleksi \\
\hline 1 & $\begin{array}{l}\text { Rata-rata kompetensi guru merancang program } \\
\text { pengayaan termasuk kategori berkompeten (B) }\end{array}$ & $81,38 \%(\mathrm{~B})$ & $\begin{array}{c}81,38 \% \geq \\
71 \%-85 \%\end{array}$ \\
\hline 2 & $\begin{array}{l}\text { Kompetensi guru merancang program pengayaan } \\
\text { yang termasuk kategori berkompeten (B) minimal } \\
\text { memenuhi 75\% }\end{array}$ & $88,88 \%$ & $88,88 \% \geq 75 \%$ \\
\hline 3 & $\begin{array}{l}\text { Rata-rata kompetensi guru melaksanakan program } \\
\text { pengayaan termasuk kategori berkompeten (B) }\end{array}$ & $84,25 \%(\mathrm{~B})$ & $\begin{array}{c}84,25 \% \geq \\
71 \%-85 \%\end{array}$ \\
\hline 4 & $\begin{array}{l}\text { Kompetensi guru melaksanakan program pengayaan } \\
\text { yang termasuk kategori berkompeten (B) minimal } \\
\text { memenuhi 75\% }\end{array}$ & $100 \%$ & $100 \% \geq 75 \%$ \\
\hline \multicolumn{1}{|c|}{ Keputusan } & \multicolumn{2}{|c|}{ Berhasil } \\
\hline
\end{tabular}

Sesuai dengan analisis data dan refleksi pada Siklus II, maka kompetensi pedagogik guru merancang program pengayaan meningkat dan termasuk kategori berkompeten (B). Kompetensi pedagogik guru merancang program pengayaan mengalami peningkatan dari kategori kurang berkompeten (D) menjadi cukup berkompeten (C) dan menjadi berkompeten (B). Peningkatan tersebut memenuhi indikator keberhasilan tindakan. Dengan demikian, tindakan pada Siklus II mampu meningkatkan kompetensi pedagogik guru merancang program pengayaan yang termasuk kategori berkompeten (B).
Sesuai dengan analisis data dan refleksi pada Siklus II, maka penelitian berlangsung sampai Siklus II dan tidak perlu dilanjutkan pada Siklus III.

\section{Pembahasan}

Kompetensi pedagogik merancang program pengayaan Guru SDN 4 Jiken pada pembelajaran di awal Semester II Tahun Pelajaran 2018/2019 dengan persentase sebesar $49,44 \%$ yang termasuk kategori kurang berkompeten (D). Kompetensi pedagogik guru dalam merancang program pengayaan tidak ada yang termasuk kategori berkompeten (B). Kompetensi pedagogik guru hanya termasuk kategori cukup berkompeten (C) sebesar 
$22,23 \%$ dan kategori kurang berkompeten sebesar $77,77 \%$.

Dalam penelitian ini, penulis sebagai Kepala Sekolah melakukan supervisi akademik dengan teknik teknik penilaian diri sendiri, yaitu menilai dirinya sendiri secara objektif. Supervisi akademik teknik penilaian diri sendiri merupakan tindak lanjut terhadap kompetensi pedagogiknya dalam merancang program pengayaan.

Pada Siklus I, penulis melakukan bimbingan dan pembinaan tentang program pengayaan, yaitu kajian teori tentang program pengayaan. Subjek penelitian merancang dan melaksanakan program pengayaan sesuai dengan hasil belajar terdahulu.

Pada Siklus II, penulis melakukan bimbingan dan pembinaan tentang bimbingan teknis, yaitu format dan sistematika tentang program pengayaan. Subjek penelitian merancang dan melaksanakan program pengayaan sesuai dengan proses dan hasil belajar berikutnya.

Sesuai dengan analisis data, kompetensi pedagogik guru dalam merancang program pengayaan melalui supervisi akademik dengan teknik penilaian diri sendiri sebagai berikut:

Grafik 4.1. Analisis kompetensi pedagogik guru dalam merancang program pengayaan.

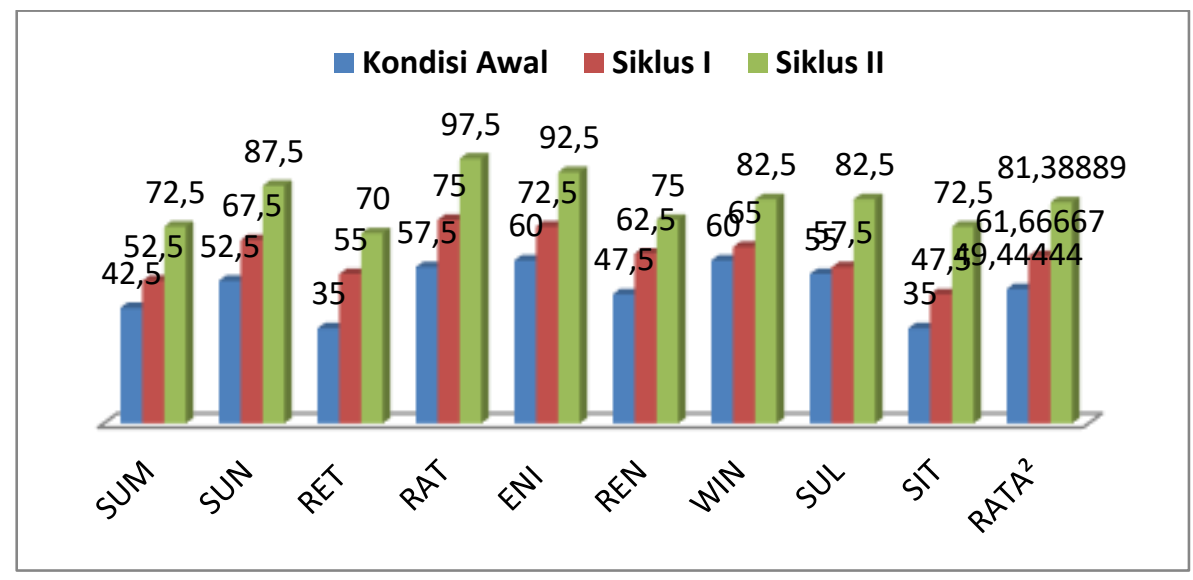

Tabel 4.8. Analisis kompetensi pedagogik guru dalam merancang program pengayaan.

\begin{tabular}{|c|l|c|c|c|}
\hline No & Nama & Kondisi Awal & Siklus I & Siklus II \\
\hline 1 & SUM & D & D & B \\
\hline 2 & SUN & D & C & A \\
\hline 3 & RET & D & D & A \\
\hline 4 & RAT & D & B & A \\
\hline 5 & ENI & D & B & B \\
\hline 6 & REN & C & C & B \\
\hline 7 & WIN & D & C & B \\
\hline 8 & SUL & D & D & B \\
\hline 9 & SIT & D & C & \\
\hline & Rata-rata & & & \\
\hline
\end{tabular}

Sesuai dengan analisis data, kompetensi pedagogik guru dalam merancang program pengayaan melalui supervisi akademik dengan teknik penilaian diri sendiri mengalami peningkatan. Pada Kondisi Awal, kompetensi pedagogik guru termasuk kategori kurang berkompeten (D) dengan persentase sebesar 49,44\% dan tidak ada yang termasuk kategori berkompeten (B). Pada Siklus I, kompetensi pedagogik guru termasuk kategori cukup berkompeten (C) dengan persentase sebesar $61,67 \%$ dan $22,23 \%$ yang termasuk kategori berkompeten (B). Pada Siklus II, kompetensi pedagogik guru termasuk kategori berkompeten (B) dengan persentase sebesar $81,38 \%$ dan $88,88 \%$ yang termasuk kategori berkompeten (B). 
Sesuai dengan analisis data, kompetensi pedagogik guru dalam merancang program pengayaan melalui supervisi akademik dengan teknik penilaian diri sendiri mengalami peningkatan dari kurang berkompeten (D) menjadi berkompeten (B).

Dalam penelitian ini, penulis sebagai Kepala Sekolah menugaskan subjek penelitian merancang dan melaksanakan program pengayaan. Pelaksanaan program pengayaan sesuai dengan jenis-jenis program pengayaan dan bentuk-bentuk program pengayaan. Pelaksanaan program pengayaan mengacu pada proses dan hasil belajar.

Sesuai dengan analisis data, kompetensi pedagogik guru dalam melaksanakan program pengayaan sebagai berikut:

Grafik 4.2. Analisis kompetensi pedagogik guru dalam melaksanakan program pengayaan.

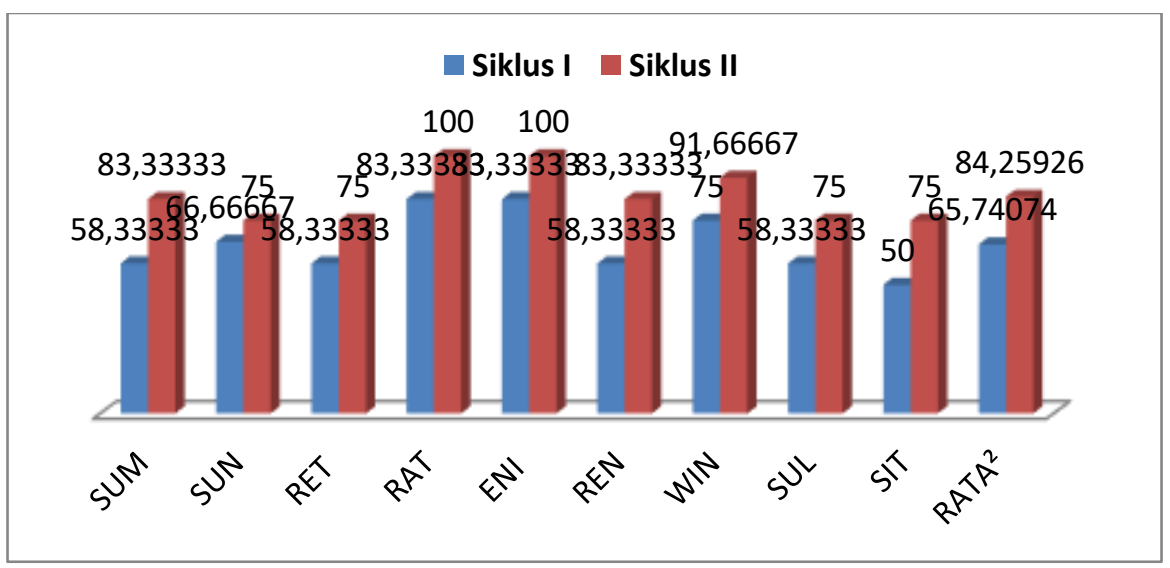

Tabel 4.9. Analisis kompetensi pedagogik guru dalam melaksanakan program pengayaan.

\begin{tabular}{|c|l|c|c|}
\hline No & \multicolumn{1}{|c|}{ Nama } & Siklus I & Siklus II \\
\hline 1 & SUM & C & B \\
\hline 2 & SUN & C & B \\
\hline 3 & RET & C & B \\
\hline 4 & RAT & B & A \\
\hline 5 & ENI & B & A \\
\hline 6 & REN & B & B \\
\hline 7 & WIN & C & B \\
\hline 8 & SUL & D & B \\
\hline 9 & SIT & C & B \\
\hline & Rata-rata & & \\
\hline
\end{tabular}

Sesuai dengan analisis data, kompetensi pedagogik guru dalam melaksanakan program pengayaan mengalami peningkatan. Pada Siklus I, kompetensi pedagogik guru termasuk kategori cukup berkompeten (C) dengan persentase sebesar $65,74 \%$ dan $33,33 \%$ yang termasuk kategori berkompeten (B). Pada Siklus II, kompetensi pedagogik guru termasuk kategori berkompeten (B) dengan persentase sebesar $84,25 \%$ dan $100 \%$ yang termasuk kategori berkompeten (B).
Sesuai dengan analisis data, kompetensi pedagogik guru dalam melaksanakan program pengayaan mengalami peningkatan dari cukup berkompeten (C) menjadi berkompeten (B).

Penilaian diri sendiri merupakan salah satu teknik supervisi individual. Menurut Anonim (2008: 25), penilaian diri sendiri memberikan informasi secara objektif kepada guru tentang peranannya di kelas dan memberikan kesempatan kepada guru mempelajari metode pengajarannya dalam mempengaruhi murid. Dalam penelitian ini, 
penilaian diri sendiri dilakukan pada pertemuan kedua sesuai dengan hasil kompetensi pedagogik guru merancang program pengayaan. Lembar penilaian diri sendiri terdiri dari sepuluh pertanyaan dengan empat pilihan jawaban. Sesuai dengan penilaian diri sendiri, subjek penelitian mengetahui kompetensi pedagogiknya dan permasalahan yang berkaitan dengan merancang maupun melaksanakan program pengayaan.

Sesuai dengan penilaian diri sendiri, permasalahan yang berkaitan dengan kompetensi pedagogik guru merancang program pengayaan diselesaikan. Menurut Prasojo dan Sudiyono (2011: 108), penilaian diri sendiri adalah penilaian yang dilakukan oleh diri sendiri secara objektif. Dalam penilaian diri sendiri diperlukan kejujuran diri sendiri. Menurut Risnawati (2012: 259), penilaian diri sendiri secara objektif membantu guru dalam memperbaiki kemampuannya. Dalam penelitian ini, penyelesaian masalah dilakukan pada pertemuan keempat.

Menurut Sukiman (2012: 52), program pengayaan adalah kegiatan yang diberikan kepada peserta didik kelompok cepat, sehingga peserta didik tersebut lebih kaya pengetahuan dan keterampilannya lebih mendalam terhadap penguasaan bahan pelajaran dan kompetensi yang mereka pelajari. Menurut Sugihartono (2012: 186), program pengayaan adalah kegiatan yang ditujukan bagi peserta didik yang memiliki kemampuan akademik yang tinggi, yang berarti mereka adalah peserta didik yang tergolong cepat dalam menyelesaikan tugas belajarnya. Menurut Kunandar (2013: 240-241), program pengayaan adalah program pembelajaran yang diberikan kepada peserta didik yang belajar lebih cepat.

Dalam penelitian ini, pelaksanaan program pengayaan subjek penelitian sesuai dengan hasil pengamatan. Sesuai dengan bimbingan dan pembinaan, kompetensi pedagogik guru merancang program pengayaan meningkat dan pelaksanaan program pengayaan juga meningkat. Pada Siklus I, kompetensi pedagogik guru termasuk kategori cukup berkompeten (C) dengan persentase sebesar $65,74 \%$ dan $33,33 \%$ yang termasuk kategori berkompeten (B). Pada Siklus II, kompetensi pedagogik guru termasuk kategori berkompeten
(B) dengan persentase sebesar 84,25\% dan $100 \%$ yang termasuk kategori berkompeten (B).

Sesuai dengan pembahasan di atas, penulis memperoleh hasil penelitian sebagai berikut:

1. Kompetensi pedagogik merancang program pengayaan Guru SDN 4 Jiken melalui supervisi akademik teknik penilaian diri sendiri Semester II Tahun Pelajaran 2018/2019 meningkat dari kategori kurang berkompeten (D) menjadi kategori berkompeten (B).

2. Kompetensi pedagogik merancang program pengayaan Guru SDN 4 Jiken melalui supervisi akademik teknik penilaian diri sendiri Semester II Tahun Pelajaran 2018/2019 yang termasuk kategori berkompeten (B) meningkat dari $0 \%$ pada Kondisi Awal menjadi 22,23\% pada Siklus I dan $88,88 \%$ pada Siklus II.

\section{KESIMPULAN}

Sesuai dengan hasil penelitian dan pembahasan, penulis menarik simpulan dalam penelitian ini adalah kompetensi pedagogik merancang program pengayaan Guru SDN 4 Jiken melalui supervisi akademik teknik penilaian diri sendiri Semester II Tahun Pelajaran 2018/2019 meningkat dari kategori kurang berkompeten (D) menjadi kategori berkompeten (B). Kompetensi pedagogik merancang program pengayaan yang termasuk kategori berkompeten (B) meningkat dari 0\% pada Kondisi Awal menjadi 22,23\% pada Siklus I dan $88,88 \%$ pada Siklus II.

\section{SARAN}

1. Bagi guru supaya merancang dan melaksanakan program pengayaan dengan mempertimbangkan jenis dan bentuk program pengayaan.

2. Bagi peserta didik supaya mengikuti program pengayaan dengan sungguhsungguh.

3. Bagi sekolah supaya melengkapi sarana dan prasarana untuk menunjang program pengayaan.

\section{DAFTAR PUSTAKA}

Anonim. 2008. Metode dan Teknik Supervisi. Jakarta: Direktoral Tenaga Kependidikan, Direktorat Jenderal 
Peningkatan Mutu Pendidik dan Tenaga Kependidikan.

---. 2011. Apa itu Penelitian Tindakan Sekolah (PTS)? Artikel dalam https://komunitasgurupkn.blogspot.com/ 2011/05/apa-itu-penelitian-tindakansekolah-pts.html?m=1 diakses pada 1 Februari 2019.

Arikunto, Suharsimi. 2004. Dasar-Dasar Supervisi. Jakarta: Rineka Cipta.

Kunandar. 2013. Penilaian Autentik: Penilaian Hasil Belajar Peserta Didik Berdasarkan Kurikulum 2013. Jakarta: Raja Grafindo Persada.

Pidarta, Made. 2009. Supervisi Pendidikan Kontekstual. Jakarta: Rineka Cipta.

Prasojo, Lantip Diat dan Sudiyono. 2011. Supervisi Pendidikan. Yogyakarta: Gava Media.

Peraturan Pemerintah Nomor 17 Tahun 2010 tentang Pengelolaan Penyelenggaraan Pendidikan.

Peraturan Pemerintah Nomor 74 Tahun 2008 tentang Guru.
Peraturan Menteri Pendidikan dan Kebudayaan Nomor 104 Tahun 2014 tentang Penilaian Hasil Belajar pada Pendidikan Dasar dan Pendidikan Menengah.

Risnawati. 2012. Administrasi dan Supervisi Pendidikan. Yogyakarta: Aswaja Pressindo.

Sagala, Syaiful. 2009. Kemampuan Profesional Guru dan Tenaga Kependidikan. Bandung: Alfabeta.

---. 2012. Supervisi Pembelajaran dalam Profesi Pendidikan. Bandung: Alfabeta.

Soetjipto dan Kosasi, Raflis. 2007. Profesi Keguruan. Jakarta: Rineka Cipta.

Sudrajat, Akhmad. 2013. Supervisi Diri untuk Pertumbuhan Profesional Guru. Dalam https://akhmadsudrajat.wordpress.com/2 013/12/31/supervisi-diri/ diakses pada 1 Februari 2019.

Sugihartono. 2012. Psikologi Pendidikan. Yogyakarta: UNY Press.

Sukiman. 2012. Pengembangan Sistem Evaluasi. Yogyakarta: Insan Madani. 